Saudi Journal of Business and Management Studies Abbreviated Key Title: Saudi J Bus Manag Stud ISSN 2415-6663 (Print) |ISSN 2415-6671 (Online) Scholars Middle East Publishers, Dubai, United Arab Emirates Journal homepage: https://saudijournals.com

Original Research Article

\title{
The Influence of Organizational Culture, Business Processes, Organizational Commitment to the Implementation of Accounting Information Systems and its Impact on the Quality of Financial Statements
} Trigus Sinduwarno ${ }^{1 *}$, Fardinal

${ }^{1}$ Department of Accounting Universitas Mercu Buana

DOI: $10.36348 / \mathrm{sjbms.2021.v06i02.002}$

| Received: 04.02.2021 | Accepted: 16.02.2021 | Published: 24.02.2021

*Corresponding author: Trigus Sinduwarno

\section{Abstract}

This study aims to examine the influence of organizational culture, business processes, and organizational commitment on the implementation of accounting information systems and their impact on the quality of financial reports. The population in this study is the Section / Subdirectorate of the National Counter-Terrorism Agency which consists of Administrator Officers (Echelon III), Supervisory Officers (Echelon IV) and Staff. The number of samples is 60 respondents who operate the accounting system, director and managerial level who use accounting information. Data were collected using a questionnaire using a Likert scale. The distribution and collection of questionnaires was carried out in April 2020. The test results showed that Organizational Culture had no effect on the Accounting Information System. Business Processes affect the Accounting Information System. Organizational Commitment affects the Accounting Information System. Organizational Culture has an effect on Financial Statements. Business processes affect financial reports. Organizational Commitment has no effect on financial statements. Organizational Culture, Business Processes, Organizational Commitment affect Financial Statements through the Accounting Information System. The level of influence and no effect is due to other factors of employee discipline, lack of mutual ownership and respect that can be obtained by employees.

Keywords: Organizational Culture, Business Processes, Organizational Commitment, Implementation of Accounting Information Systems, Quality of Financial Statements.

Copyright () 2021 The Author(s): This is an open-access article distributed under the terms of the Creative Commons Attribution 4.0 International License (CC BY-NC 4.0) which permits unrestricted use, distribution, and reproduction in any medium for non-commercial use provided the original author and source are credited.

\section{INTRODUCTION}

The development of the world of technology seems to be increasingly advanced both in the private and government sectors. In the face of a time of rapid technological disruption, of course, accounting plays a part in carrying out its role. Human resources must be able to adapt to technology in a flexible manner, where an accountant who works as an accountant must follow the rapid trend of information technology. Human resources in carrying out their roles, both in the public and private sectors, need a system that can support them in this direction.

Meanwhile, according to Government Regulation (PP) Number 71 Year 2010 Quality financial reports are financial reports that have relevant, reliable, comparable and understandable characteristics. According to Kieso, Weygandt and Warfield [1], defining financial statements as the main means of communicating financial information to people outside the company. A good financial report is expected to be presented in a proper, clear, and complete manner in order to reveal the company's economic events.

Organizational culture can also be an obstacle to a change when shared values are not in line with values that can increase organizational effectiveness. However, organizational culture is one that enables the implementation of accounting information systems to be successful Claver,. 2001 [2] in Maryana [3]. 
Trigus Sinduwarno \& Fardinal., Saudi J Bus Manag Stud, Feb, 2021; 6(2): 39-50

According to Wager [4], the most important activity in implementing an old system (system maintenance) and a new system is to evaluate existing business processes or workflows. Accounting Information Systems require business process expertise in the main and supporting business as well as the business context (business strategy) in facing the era of business competition [5].

Organizational commitment can also be one of the important things in the successful implementation of an accounting information system, as stated by Larsen 2003 [6] in Adli Anwar [7] where there are several determining factors (antecedent) of accounting information systems, one of which is organizational commitment which is defined as someone's attachment to always working in an organization.

Phenomenon that occurs in the National Counter-Terrorism Agency, namely sprins, official notes are often late so that it has an impact on the implementation of the accounting information system, which results in the system processing being less timely, effective and efficient. In addition, the presentation of the financial statements has not yet proceeded according to the objectives achieved. This can disrupt work and can affect the financial reports of the National Counterterrorism Agency which will certainly be an interesting lesson for all government agencies, especially regarding how effective supervision should be built.

Based on the description of the above phenomena, the authors identify the formulation of causality problems between Organizational Culture, Business Processes, Organizational Commitment to Accounting Information System Implementation and the Quality of Financial Statements.

1) Does organizational culture affect the implementation of accounting information systems?

2) Does the business process affect the implementation of the accounting information system?

3) Does organizational commitment affect the implementation of accounting information systems?

4) Does the implementation of the accounting information system affect the financial statements?

This research was conducted to prove the theories and hypotheses in previous studies regarding the factors that affect the quality of the accounting information system and their impact on the quality of financial reports with the relationship between research variables as follows:

1) The influence of organizational culture on the implementation of accounting information systems.

2) The influence of business processes on the implementation of accounting information systems
3) The effect of organizational commitment on the implementation of the accounting information system.

4) The effect of accounting information system implementation on financial reports.

Research on Organizational Culture, Business Processes, Organizational Commitment to Accounting Information System Implementation and its Impact on the Quality of Financial Statements has been widely conducted. Among them is research conducted by Azhar Susanto 2013 [9], in a study entitled "Accounting Information Systems, Control Structures - Development Risks". Discusses organizational culture and organizational commitment have an influence on accounting information systems.

Azmi Fitriati, Sri Mulyani [8] in a study entitled 'Factors that Affect Accounting Information System Success and its Implication on Accounting Information Quality' discusses organizational commitment and organizational culture has an influence on the Accounting Information System.

Wayan Purwa Abhimantra and I Ketut Suryanawa [10] in a study entitled Analysis of Factors Affecting the Performance of Accounting Information Systems discusses user involvement, personal technical skills, top management support, formalization of system development, training and education have a positive effect on the performance of accounting information systems.

Based on the background described above, the authors intend to conduct research using different variables from previous studies entitled "The Influence of Organizational Culture, Business Processes, Organizational Commitment to Information System Implementation and Its Impact on the Quality of Financial Statements.

\section{LITERATURE REVIEW Organizational culture}

Organizational culture is a system of spreading beliefs and values that develops within an organization and directs the behavior of its members. Organizational culture can be a major competitive advantage instrument, that is, if the organizational culture supports the organizational strategy. Robbins [11] defines organizational culture as a system of shared meanings shared by members that differentiates the organization from other organizations. Schein [12] defines organizational culture as a pattern of basic assumptions that a group of people finds or develops as they learn to solve problems, adapt to the external environment, and integrate with the internal environment.

Azhar Susanto [13] provides an explanation of organizational culture as a method used by human resources within the organization. Culture is a daily internal environment that is seen and felt by those who work in it, and is the result of a cumulative learning 
Trigus Sinduwarno \& Fardinal., Saudi J Bus Manag Stud, Feb, 2021; 6(2): 39-50

process for human resources as a reflection of promotions, rewards, punishments and decisions set by an organization.

Sutrisno [14] affirms that organizational culture is a system of values, beliefs or norms that have long been valid, agreed upon and followed by members of an organization as a guide for behavior and solving organizational problems. .

\section{Business process}

Hammer and Champy [15] state that a business process is a set of activities that require one or more input / input and form an output that has the value the customer wants. According to Wikipedia Indonesia, a business process is a structured collection of activities or work that are interrelated to solve a particular problem or produce a product or service to achieve a specific goal.

According to Whitten [16] business process analysis is a study and evaluation of the company's business process activities to identify the impact of these activities in creating value or adding value to the company's business. Business process analysis is one of the activities that a company must undertake when the company is going to reengineer its business processes

\section{Organizational Commitment}

Robbins and Judge [11] define commitment as a condition in which an individual sides with the organization and its goals and desires to maintain its membership in the organization. Whereas an organization is a consciously coordinated social unit consisting of two or more people and functions on a relatively continuous basis in order to achieve one or a series of common goals. According to Taurisa \& Ratnawati [17] organizational commitment means more than just passive loyalty, but also involves active relationships and the desire of employees to make meaningful contributions to their organization. Richard M. Steers [18] defines organizational commitment as a sense of identification (belief in organizational values), involvement (willingness to do the best possible for the benefit of the organization) and loyalty (the desire to remain a member of the organization concerned) expressed by an employee. Against the organization.

\section{Accounting Information System Implementation}

Information systems are a set of interconnected components that function to collect, process, store, and distribute information to support satisfaction creation and supervision in the organization [19]. Then Bodnard and Hopwood [20] state that computer-based information systems are a group of hardware and software designed to convert data into useful information.

The variables of Information Quality and System Quality independently and collectively affect the Usage and User Satisfaction variables, the Usage variable affects User Satisfaction and vice versa, then Usage and User Satisfaction together affect Individual Impact then Organizational Impact [21]. The higher the quality of information and the quality of the system can increase user satisfaction and increase individual and organizational productivity.

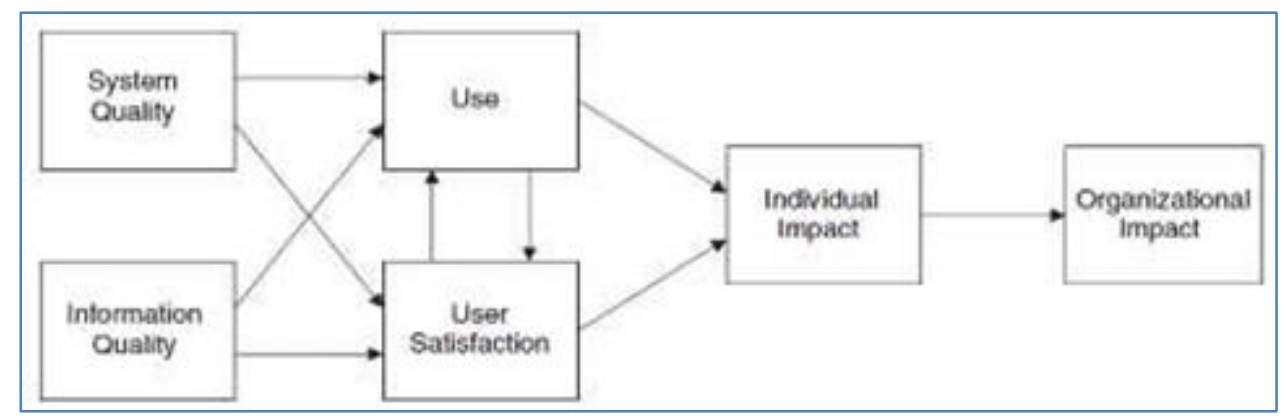

Figure De Lone and McLean's 1992 Information System Success Model

System quality is the performance in the system itself, the measurement of system quality is influenced by ease of use, ease of learning, system features, and system accuracy, flexibility [22]. According to DeLone and McLean [21], system quality is a characteristic of the desired quality of quality information and information systems desired information on product characteristics. System quality is the quality of the combination of hardware and software in information systems. The quality of the system requires indicators to be able to measure how much the quality of the system is. Indicators are needed because system quality is a latent variable that cannot be measured directly.

\section{Financial Report Quality}

Baridwan [23] defines financial statements as a summary of a recording process, which is a summary of financial transactions that occurred during the financial year concerned. This financial report is prepared by management with the aim of being accountable for the tasks assigned to it by the company owners. 
According to Kasmir [24], financial statements are defined as reports that show the company's current financial condition or within a certain period.

According to PP. 71/2010, the qualitative characteristics of financial statements are normative measures that need to be translated into accounting information so that it can fulfill its objectives

\section{HYPOTHESIS}

H1: Organizational culture affects the Implementation of Accounting Information Systems.

H2: Business Processes affect the Implementation of Accounting Information Systems.

H3: Organizational Commitment affects the Implementation of Accounting Information Systems.

H4: Accounting Information System Implementation affects the Quality of Financial Statements.

\section{RESEARCH METHODOLOGY}

\section{RESULTS. RESPONDENT DESCRIPTION}

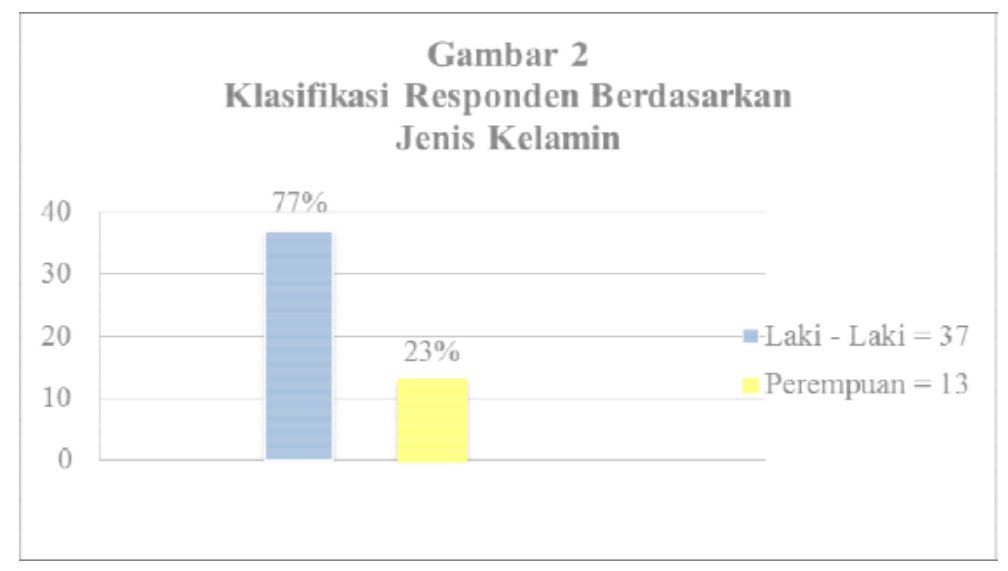

Based on the picture above, it can be seen that the questionnaires distributed were 51 copies with a $100 \%$ return rate. Of the 37 respondents who were
This research is a type of causal research. Causal research aims to test hypotheses about the effect of one or more variables (independent variables) on other variables (dependent variable). The data contained in this study is in the form of a questionnaire so that it is included in quantitative research. This study uses primary data in the form of answers from respondents from the sub-directorate / head of division to the staff at the research site.

The population of this research is the Section / Sub-directorate of the National Counterterrorism Agency which consists of Administrator Officers (Echelon III), Supervisory Officers (Echelon IV) and Staff. The total number of respondents was 60 users of the accounting information system, financial statements or accounting information. In this study, data collection was carried out using a Likert scale questionnaire technique. And the method of analysis in this research is the Structural Equation Model (SEM) with the help of Partial Least Square Software (PLS), namely SmartPLS version 3.0. for measuring the level of validation and reliability of data and descriptive analysis. male, $77 \%$ or a total of 37 respondents, while $23 \%$ or 13 respondents were female.

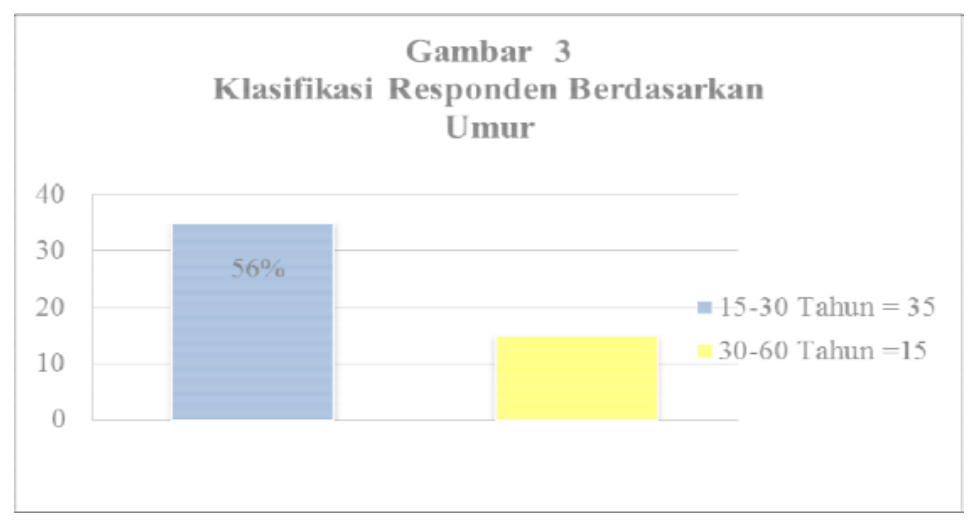


Trigus Sinduwarno \& Fardinal., Saudi J Bus Manag Stud, Feb, 2021; 6(2): 39-50

Based on the picture above, it can be seen that the questionnaires distributed were 71 copies with a $100 \%$ return rate. Of the 71 respondents aged 15-30 years, $56 \%$ or a total of 35 respondents, while the female sex was $44 \%$ or 15 respondents.

\section{Descriptive Statistics Test Results Table}

Descriptive Statistics

\begin{tabular}{|l|c|c|c|c|r|}
\hline & & Minimu & Maxim & & Std. \\
\hline & $\mathrm{N}$ & $\mathrm{m}$ & um & Mean & Deviation \\
\hline TOTAL_X1 & 50 & 51.00 & 65.00 & 59.7000 & 3.60979 \\
\hline TOTAL_X2 & 50 & 31.00 & 44.00 & 40.0400 & 2.69512 \\
\hline TOTAL_X3 & 50 & 57.00 & 78.00 & 68.2000 & 4.47214 \\
\hline TOTAL_Y & 50 & 50.00 & 67.00 & 58.5200 & 4.36236 \\
\hline TOTAL_Z & 50 & 34.00 & 44.00 & 39.8400 & 2.88104 \\
\hline Valid N & 50 & & & & \\
\cline { 1 - 1 } (listwise) & & & & & \\
\hline
\end{tabular}

From the table it is known that there are 5 test data (N) or respondents and it can be interpreted as follows

1. The Organizational Culture Variable (X1) has the smallest (minimum) value of 51 with the highest (maximum) value of 65 , while the mean value is 59.7000 and the standard deviation (Std Deviation) is 3.60979 .

2. The Business Process Variable (X2) has the smallest (minimum) value of 31 with the highest (maximum) value of 44 , while the average (mean) value is 40.0400 and the standard deviation (Std Deviation) is 2.69512.

3. The Organizational Commitment variable (X3) has the smallest (minimum) value of 57 with the highest (maximum) value of 78 , while the average (mean) value is 68.2000 and the standard deviation (Std Deviation) is 4.47214.

4. The Accounting Information System variable (Y) has the smallest (minimum) value of 50 with the highest (maximum) value of 67 , while the average (mean) value is 58,5200 and the standard deviation (Std Deviation) is 36236.

5. The Financial Statement variable (Y) has the smallest (minimum) value of 34 with the highest (maximum) value of 44 , while the average (mean) value is 39.8400 and the standard deviation (Std Deviation) is 2.88104 .

\section{Evaluation of Outer Model Testing}

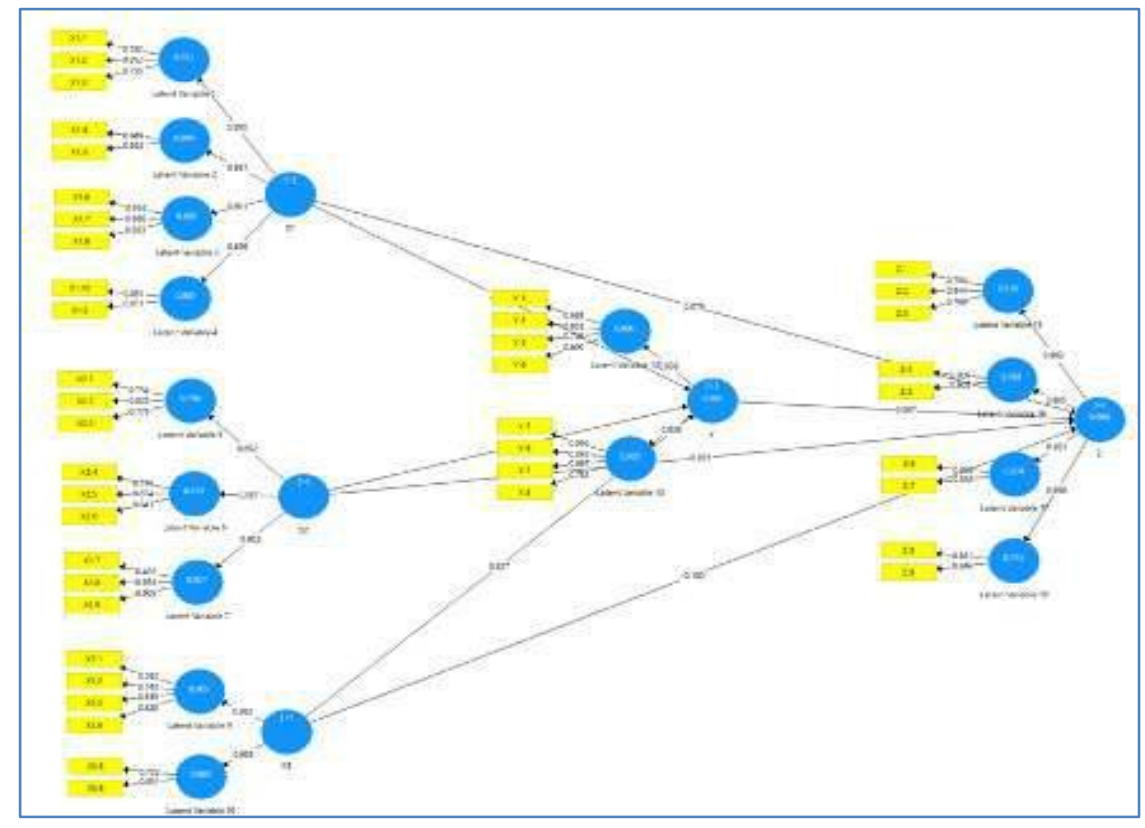

First Outer Loadings Image

Based on the data presentation in the image above, it is known that each indicator of the research variables has an outer loading value of $>0.5$. However, it appears that there are still several indicators that have 
Trigus Sinduwarno \& Fardinal., Saudi J Bus Manag Stud, Feb, 2021; 6(2): 39-50

outer loading values $<0.5$. The data above shows that there is a variable indicator whose outer loading value is below 0.5 , so that some indicators are dropped and can be carried out for further analysis.

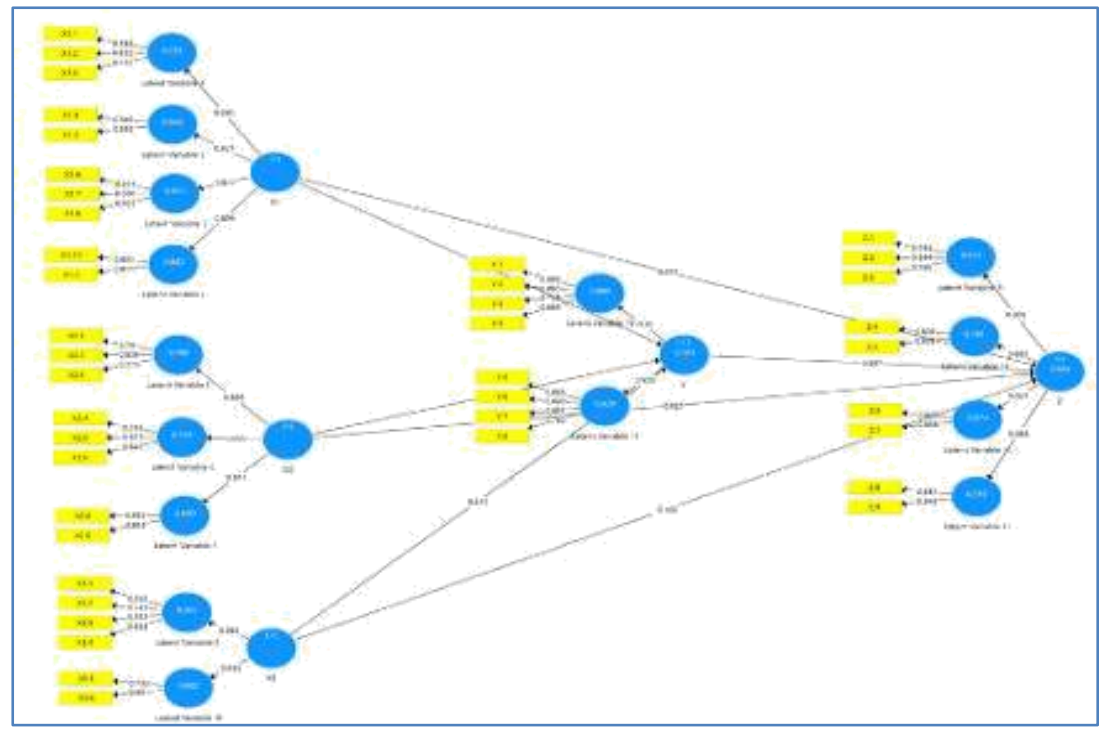

Second Outer Loadings Image

Based on the results of the validity test, it can be concluded that all variable items consisting of Organizational Culture, Business Processes, Organizational Commitment to Accounting Information Systems and their impact on Financial Statements are valid.

AVE Reliability Test Table

\begin{tabular}{|c|c|}
\hline Variabel & AVE \\
\hline Organizational Culture (X1) & 0.547 \\
\hline Business Process (X2) & 0.559 \\
\hline Organizational Commitment (X3) & 0.555 \\
\hline Accounting Information Systems (Y) & 0.551 \\
\hline Financial Statements (Z) & 0.538 \\
\hline
\end{tabular}

Based on the data presentation in the table above, it is known that the AVE value of the variable Organizational Culture (X1), Business Process (X2), Organizational Commitment (X3) on the Accounting Information System (Y) and its impact on Financial Statements $(Z)>0.5$ so that It can be said that the variable Organizational Culture (X1), Business Process (X2), Organizational Commitment (X3) to the Accounting Information System (Y) and its impact on Financial Statements (Z) have high discriminant validity.

Composite Reliability Test Table

\begin{tabular}{|l|c|}
\hline \multicolumn{1}{|c|}{ Variabel } & Composite \\
\cline { 2 - 2 } & Realiability \\
\hline Organizational Culture (X1) & 0.921 \\
\hline Business Process (X2) & 0.916 \\
\hline $\begin{array}{l}\text { Organizational Commitment } \\
\text { (X3) }\end{array}$ & 0.880 \\
\hline Accounting Information Systems & 0.906 \\
\hline (Y) & \\
\hline
\end{tabular}

\begin{tabular}{|l|l} 
Financial Statements (Z) & 0.911
\end{tabular}

Based on the data presentation in the table above, it can be seen that the composite reliability value of all research variables is $>0.7$. It can be concluded that all variables have a high level of reliability.

Cronbach's Alpha Reliability Test Table

\begin{tabular}{|l|c|}
\hline & Cronbac \\
\hline \multicolumn{1}{|c|}{ Variabel } & hs \\
\hline & Alpha \\
\hline Organizational Culture (X1) & 0.903 \\
\hline & \\
\hline Business Process (X2) & 0.895 \\
\hline Organizational Commitment (X3) & 0.835 \\
\hline Accounting Information Systems (Y) & 0.879 \\
\hline Financial Statements (Z) & 0.887 \\
\hline
\end{tabular}

Based on the data presentation in the table above, it can be seen that the Cronbach's alpha value of each research variable is $>0.7$. Thus these results indicate that each research variable has met the requirements for the Cronbach's alpha value, so it can be concluded that all variables have a high level of reliability.

\section{Evaluation Table of the Structural Model}

Goodness of Fit (Inner Model)

\begin{tabular}{|c|c|c|}
\hline & R & R Square \\
\hline Variabel & & \\
\cline { 1 - 1 } & Square & Adjust \\
\hline Accounting Information & 0,104 & 0,053 \\
\cline { 1 - 1 } Systems (Y) & & \\
\hline Financial Statements & 0.988 & 0.987 \\
\hline
\end{tabular}


Trigus Sinduwarno \& Fardinal., Saudi J Bus Manag Stud, Feb, 2021; 6(2): 39-50

\section{(Z)}

Based on the data presentation in the table above, it can be seen that the R-Square value for the Accounting Information System

(Y) Variable is 0.104 and the obtained value explains that the percentage of the variable explained is $10.40 \%$ while the rest is influenced by other variables. Financial Statement variable

(Z) The report is 0.988 and the value acquisition explains that the percentage of the variable explained is $98.80 \%$ while the rest is influenced by other variables.

Hypothesis Testing Results Table

\begin{tabular}{|c|c|c|c|c|c|}
\hline Hypothesis & Variabel & $\begin{array}{l}\text { Parameter } \\
\text { Coefficient }\end{array}$ & T Statistics & P Value & Information \\
\hline H1 & $\begin{array}{l}\text { Organization } \\
\text { al Culture } \\
(\mathrm{X} 1)=> \\
\text { Accounting } \\
\text { Information } \\
\text { Systems (Y) }\end{array}$ & $-0,685$ & 1.176 & 0.240 & $\begin{array}{c}\text { Not } \\
\text { significant }\end{array}$ \\
\hline $\mathrm{H} 2$ & $\begin{array}{c}\text { Business } \\
\text { Process }(\mathrm{X} 2)=> \\
\text { Accounting } \\
\text { Information } \\
\text { Systems (Y) }\end{array}$ & 0,104 & 0.706 & 0.480 & $\begin{array}{c}\text { Not } \\
\text { significant }\end{array}$ \\
\hline H3 & $\begin{array}{c}\text { Organization } \\
\text { al } \\
\text { Commitment }(\mathrm{X} 3)=> \\
\text { Accounting } \\
\text { Information } \\
\text { Systems (Y) }\end{array}$ & 0.419 & 0,693 & 0.488 & $\begin{array}{c}\text { Not } \\
\text { significant }\end{array}$ \\
\hline H4 & $\begin{array}{c}\text { Organization } \\
\text { al Culture }(\mathrm{X} 1)=> \\
\text { Financial } \\
\text { Statements } \\
(\mathrm{Z})\end{array}$ & 0.079 & 1.239 & 0.216 & $\begin{array}{c}\text { Not } \\
\text { significant }\end{array}$ \\
\hline H5 & $\begin{array}{c}\text { Business } \\
\text { Process }(\mathrm{X} 2)=>\text { Financial } \\
\text { Statements } \\
(\mathrm{Z})\end{array}$ & 0,021 & 1.007 & 0.315 & $\begin{array}{c}\text { Not } \\
\text { significant }\end{array}$ \\
\hline H6 & $\begin{array}{c}\text { Organization } \\
\text { al } \\
\text { Commitment }(\mathrm{X} 3)=> \\
\text { Financial } \\
\text { Statements } \\
(\mathrm{Z}) \\
\end{array}$ & $-0,100$ & 1.559 & 0.120 & $\begin{array}{c}\text { Not } \\
\text { significant }\end{array}$ \\
\hline $\mathrm{H} 7$ & $\begin{array}{c}\text { Accounting } \\
\text { Information Systems => } \\
\text { Financial } \\
\text { Statements } \\
(\mathrm{Z})\end{array}$ & 0,987 & $\begin{array}{c}131.9 \\
55\end{array}$ & \multicolumn{2}{|c|}{0.000 significant } \\
\hline
\end{tabular}

The effect of the relationship between exogenous latent variables on endogenous latent variables in the table above can be explained as follows:

1. The coefficient of path parameters obtained from Organizational Culture (X1) on the Accounting Information System (Y) is -0.685 with a t-statistic value of $1.176<1.674$ at a significance level above 5\% (significant) which states that there is a negative influence and no significant between Organizational
Culture (X1) on Accounting Information Systems (Y) so that the first hypothesis (H1) is rejected.

2. The coefficient of path parameters obtained from the Business Process (X2) on the Accounting Information System (Y) is 0.104 with a t-statistic value of $0.706<1.674$ at a significance level above 5\% (significant) which states that there is an insignificant positive influence between Business Process 
Trigus Sinduwarno \& Fardinal., Saudi J Bus Manag Stud, Feb, 2021; 6(2): 39-50

(X2) on Accounting Information Systems (Y) so that the second hypothesis $(\mathrm{H} 2)$ is rejected.

3. The path parameter coefficient obtained from organizational commitment (X3) to the Accounting Information System (Y) is 0.419 with a t-statistic value of $0.693<1.674$ at a significance level above 5\% (significant) which states that there is an insignificant positive influence between organizational commitment (X3) to the Accounting Information System (Y) so that the third hypothesis (H3) is rejected.

4. The coefficient of path parameters obtained from Organizational Culture (X1) on Financial Statements $(\mathrm{Z})$ is 0.079 with a t-statistic value of $1.239<1.674$ at a significance level above $5 \%$ (significant) which states that there is a negative and insignificant influence between Organizational Culture (X1) on Financial Statements

(Z) so that the fourth hypothesis $(\mathrm{H} 4)$ is rejected.

5. The coefficient of path parameters obtained from the Business Process (X2) on Financial Statements $(\mathrm{Z})$ is 0.021 with a t-statistic value of $1.007<1.674$ at a significance level above $5 \%$ (significant) which states that there is an insignificant positive influence between the Process Business (X2) Financial Statements (Z) so that the fifth hypothesis (H5) is rejected.

6. The coefficient of path parameters obtained from organizational commitment (X3) to Financial Statements $(\mathrm{Z})$ is -0.100 with a tstatistic value of $1.559<1.674$ at a significance level above $5 \%$ (significant) which states that there is a negative and insignificant influence between organizational commitment (X3) to Financial Statements $(Z)$ so that the sixth hypothesis (H6) is rejected..

7. The $\mathrm{P}$ value of the Accounting Information System variable on financial statements is 0,000 with a statistical value of $131,955>$ 1,674 at a significance level of $\mathrm{a}=0.05(5 \%)$ which states that there is a positive and significant influence on Organizational Culture (X1), Business Process (X2), Organizational Commitment (X3) to Financial Statements (Z) through the Accounting Information System (Y) the sixth hypothesis (H6) is accepted.

\section{DISCUSSION}

\section{1). The Influence of Organizational Culture on Accounting Information Systems}

Based on the results of testing the first hypothesis it can be concluded that there is a negative and insignificant influence between Organizational Culture (X1) on Accounting Information Systems (Y). As expressed by Hendra Ronaldi [25] in his journal entitled "Analysis of factors that affect the performance of accounting information systems", states that user involvement has a significant negative effect on user satisfaction of AIS.

At the location of the research object, organizational culture has been implemented by issuing a Regulation of the Head of the BNPT concerning Bureaucratic Reform to support institutional performance in improving the quality of accounting information systems and the quality of financial reporting.

As also conveyed by Prof. Azhar Susanto [13] in his journal entitled 'Information Systems, Development Risk-Control Structure', that organizational commitment and organizational culture have a significant influence on the quality of accounting information systems. However, the results of the research contradict what has been implemented at BNPT. There may be other factors that influence, including User Discipline, or the quality of the accounting information system.

\section{2). The Influence of Business Processes on Accounting Information Systems}

Based on the results of testing the second hypothesis it can be concluded that there is a positive and insignificant influence between Business Process (X2) on Accounting Information Systems (Y). As expressed by Rizki Respati Prabowo, Sukirman, Nurhasan Hamidi [26] in his journal entitled "Factors that influence the Performance of the Accounting Information System in Surakarta Commercial Bank", that the ability of users, top management support has an influence on the performance of SIA.

At the place of the research object, the business process regarding the authentication flow that is too long affects the AIS and the quality of financial reporting so that the business process has a positive but insignificant effect. This is due to other factors that influence it, namely the internal audit conducted by the inspectorate and verification from the Finance Department.

As stated by Indah Widiastuti [27] in her journal entitled 'Euro adoption and the quality of accounting information', that with the existence of an accounting-based SIA, skilled human resources in finance and computer technology are also needed.

\section{3). The Effect of Organizational Commitment on Accounting Information Systems}

Based on the results of testing the third hypothesis it can be concluded that there is a positive and insignificant influence between Organizational Commitment (X3) on Accounting Information Systems (Y). As expressed by Wayan Purwa Abhimantra, I Ketut Suryanawa 2016 in his journal entitled 'Analysis of factors that affect the performance of accounting 
Trigus Sinduwarno \& Fardinal., Saudi J Bus Manag Stud, Feb, 2021; 6(2): 39-50

information systems', that user involvement, personal technical skills, top management support, formalization of system development, training and education have a positive effect. On the performance of accounting information systems.

At the place of the research object, organizational commitment has been implemented by issuing a Regulation of the Head of BNPT concerning Bureaucratic Reform to support institutional performance and implement government programs to realize excellent quality in services so as to improve the quality of accounting information systems and the quality of financial reporting.

As stated by Ronny Andesto and Azhar Susanto 2018 [9] in a study entitled The effect of Organizational Structure on Quality of Management Accounting Information. Systems (Survey on Indonesia State-own enterprise), that organizational structure has a significant effect on the Quality Management Accounting Information System. . The lack of quality management accounting information systems is caused by a lack of organizational structure. The quality of management accounting information systems can be improved by increasing the effectiveness of the organizational structure. However, the results of the study contradict what has been implemented at BNPT. There may be other factors that influence such as lack of feeling of belonging, employee compliance and reward / punishment applied to employees.

\section{4). The Influence of Organizational Culture on Financial Statements}

Based on the results of testing the fourth hypothesis it can be concluded that there is a positive and insignificant influence between Organizational Culture (X1) on Financial Statements (Z) as stated by Pradana 2013 [28] in his journal, it states that organizational culture has a positive effect on information quality.

At the location of the research object, organizational culture has been implemented by issuing a Regulation of the Head of the BNPT concerning Bureaucratic Reform to support institutional performance in improving the quality of accounting information systems and the quality of financial reporting.

As also conveyed by Azmi Fitriati, Sri Mulyani [8] in their journal entitled 'Factor that affect accounting information system success and its information on accounting information quality', that organizational commitment and organizational culture have a significant influence on the quality of the accounting information system. And the quality of AIS has a significant effect on the quality of financial reports. However, the results of the research are contradictory to what has been implemented at the
BNPT. There may be other factors that influence including employee discipline, or employee integrity.

\section{5). The Effect of Business Processes on Financial Statements}

Based on the results of testing the fifth hypothesis, it can be concluded that there is a positive and insignificant influence between Business Processes (X2) on Financial Statements (Z). As stated by Ruhul Fitrios [29] in his journal entitled 'Factors that influence accounting information system implementation and accounting information quality', top management commitment and user training have a significant impact on the quality of SIA. And the implementation of AIS has an impact on the quality of financial reports.

In the place of the research object, the impact of authentication that is too long affects the AIS and the quality of financial reporting so that business processes have a positive but insignificant effect. This is due to other factors that influence it, namely that the paperless or E-office program has not been implemented to shorten the time for correspondence authentication.

As stated by Indah Widiastuti [27] in her journal entitled 'Euro adoption and the quality of accounting information', that with the existence of an accountingbased SIA, skilled human resources in finance and computer technology are also needed.

\section{6). The Effect of Organizational Commitment on Financial Statements}

Based on the results of testing the sixth hypothesis, it can be concluded that there is a negative and insignificant influence between Organizational Culture (X3) on Financial Statements (Y). As expressed by Hendra Ronaldi [25] in his journal entitled "Analysis of factors that affect the performance of accounting information systems", mentions that top management support and the formalization of system development have a positive effect on SIA user satisfaction.

At the location of the research object, organizational culture has been implemented by issuing a Regulation of the Head of the BNPT concerning Bureaucratic Reform to support institutional performance in improving the quality of accounting information systems and the quality of financial reporting.

As also stated by Dr. Hari Setyawati2013 [30] in his journal entitled 'The effect of Internal Accountants' Competence, Managers' Commitment to Organizations and the Implementation of the Internal Control System on the Quality of Financial Reporting', states that managers' commitment to the organization has a positive influence on reports finance. However, the results of the study contradict what has been 
Trigus Sinduwarno \& Fardinal., Saudi J Bus Manag Stud, Feb, 2021; 6(2): 39-50

implemented at BNPT. There may be other factors that influence, including lack of feeling of belonging, employee compliance and reward / punishment applied to employees.

\section{7). The Influence of Organizational Culture, Business Processes, Organizational Commitment to Financial Statements through the Accounting Information System}

Based on the results of testing the first hypothesis it can be concluded that there is a positive and significant influence between Organizational Culture, Business Processes, and Organizational Commitment to Financial Statements through the Accounting Information System. As stated by Ruhul Fitrios [31] in his journal entitled 'Factors that influence accounting information system implementation and accounting information quality', top management commitment and user training have a significant impact on the quality of SIA. And the implementation of AIS has an impact on the quality of financial reports. As stated by Prof. Azhar Susanto 2013 in his journal entitled 'Information Systems, Development RiskControl Structure', that organizational commitment and organizational culture have a significant influence on the quality of accounting information systems.

In the place of research objects, organizational culture, business processes, organizational commitment to Financial Statements through the Accounting Information System have been implemented with the issuance of the Head of the BNPT Regulation regarding Bureaucratic Reform and the Circular of the Main Secretary of BNPT regarding the Verification and Accounting System (SIVERA) to support institutional performance in improving quality accounting information systems and financial reporting quality.

As also conveyed by Azmi Fitriati, Sri Mulyani 2015 [8] in their journal entitled 'Factor that affect accounting information system success and its information on accounting information quality', that organizational commitment and organizational culture have a significant influence on the quality of the accounting information system. And the quality of AIS has a significant effect on the quality of financial reports.

As also stated by Ade-ratna Komala 2012 [30] in her journal entitled 'The Influence Of The Accounting Managers' Knowledge And The Top Managements' Support On The Accounting Information System And Its Impact On The Quality Of Accounting Information: A Case Of Zakat Institutions In Bandung, that management support has an impact on the quality of AIS and on the quality of financial reports.

\section{CONCLUSION}

1. Organizational Culture has a negative and insignificant effect on the Accounting
Information System. This is caused by other factors that influence including User Discipline, or from the quality of the accounting information system.

2. Business Process has a positive and insignificant effect on the Accounting Information System. This is due to other factors that influence it, namely the internal audit conducted by the inspectorate and verification from the Finance Department

3. Organizational Commitment has a positive and insignificant effect on the Accounting Information System. This is due to other factors that influence it, namely the existence of the Head of the BNPT Regulation regarding Bureaucratic Reform which benchmarks on Employee Performance.

4. Organizational Culture has a positive and insignificant effect on financial statements. This is due to other factors that influence it, namely the existence of the Head of the BNPT Regulation regarding Bureaucratic Reform which benchmarks on Employee Performance.

5. Business Process has a positive and insignificant effect on financial statements. This is due to other factors that influence it, namely that the paperless or E-office program has not been implemented to shorten the time for correspondence authentication.

6. Organizational Commitment has a negative and insignificant effect on financial statements. This is due to other factors that influence it, namely a lack of feeling of belonging, employee compliance and reward / punishment applied to employees.

7. Organizational Culture, Business Processes, Organizational Commitment have a positive and significant effect on Financial Statements through the Accounting Information System. This is due to the issuance of the Head of the BNPT Regulation regarding Bureaucratic Reform and the Circular of the Main Secretary of the BNPT regarding the Verification and Accounting System (SIVERA) to support institutional performance in improving the quality of accounting information systems and the quality of financial reporting.

\section{RECOMMENDATIONS}

\section{For the National Counter-Terrorism Agency}

a. To overcome the decline in the quality of financial reports, it is advisable to promote the socialization of the Head of the BNPT Regulation on Bureaucratic Reform in order to improve employee performance.

b. To overcome the decline in the quality of financial reports, it is advisable to make a Regulation of the Head of the BNPT regarding rewards and punishments in order to stimulate the morale of employees in each work unit. 
Trigus Sinduwarno \& Fardinal., Saudi J Bus Manag Stud, Feb, 2021; 6(2): 39-50

c. To overcome the decline in the quality of financial reports, it is advisable to create an Eoffice so as to minimize the time in making official notes and orders.

\section{For Academics}

a. For further research, it is recommended to use other variables that can affect the Accounting Information System (Y) and its impact on Financial Statements (Z) including: User Satisfaction, Employee Discipline and Internal Audit.

b. This study experienced a limited number of populations and a small sample which resulted in the sensitivity of the measurement for Cronbach alpha resulting in values below the standard reference data validity. Further research is expected to expand research not only in city government offices but also research at provincial government agencies and local government agencies in other regions so that the data obtained is broader and can be compared between one agency and another.

\section{REFERENCES}

1. Keiso, D. E., Weygandt, J. J., \& Warfield, T. D. (2010). International Accounting.

2. Hydroformylation, R. C., van Leeuwen, P. W. N. M., \& Claver, C. (2001). Kluwer Academic Publishers: Norwell, MA, 2000.(d) Breit, B.; Seiche, W. Synthesis, 1.

3. Maryana, R., \& Rachmawati, Y. (2013). Pengelolaan lingkungan belajar. Prenada Media.

4. Wager, T. D., Waugh, C. E., Lindquist, M., Noll, D. C., Fredrickson, B. L., \& Taylor, S. F. (2009). Brain mediators of cardiovascular responses to social threat: part I: reciprocal dorsal and ventral sub-regions of the medial prefrontal cortex and heart-rate reactivity. Neuroimage, 47(3), 821-835.

5. Gelinas, Ulric. Oram, Alan, E., Wiggins, William, P. (1990). Accounting Information System. PWSKENT publishing Company. (Memuat informasi mengenai definisi system informasi).

6. Lee, Y., Kozar, K. A., \& Larsen, K. R. (2003). The technology acceptance model: Past, present, and future. Communications of the Association for information systems, 12(1), 50.

7. Ismail, A. S., Takip, K. M., Ariff Mustafa, M. K., \& Anwar, A. A. (2012). RTP: Radionuclides inventories calculation using ORIGEN Code.

8. Azmi, F., \& Harry, S. (2017). Kajian Kualitas Sistem Informasi Akuntansi pada Perguruan Tinggi Muhammadiyah di Indonesia. Prosiding Simposium Nasional Akuntansi XX Jember.

9. Andesto, R., \& Susanto, A. (2018). The Effect of Organizational Structure on Quality of Management Accounting Information Systems (Survey on Indonesia State-Owned Enterprise).
Journal of Engineering and Applied Sciences, 13(8), 2062-2067.

10. Hudin, J. M., \& Riana, D. (2016). Kajian Keberhasilan Penggunaan Sistem Informasi Accurate Dengan Menggunakan Model Kesuksesan Sistem Informasi Delon Dan Mclean. Jurnal Sistem Informasi, 12(1), 1-8.

11. Robbins, T. (2002). The 5-choice serial reaction time task: behavioural pharmacology and functional neurochemistry. Psychopharmacology, 163(3), 362-380.

12. Schein, E. H. (1985). Defining organizational culture. Classics of organization theory, 3(1), 490502.

13. Susanto, A. (2017). How the quality of accounting information system impact on accounting information quality (Research on Higher Education in Bandung). Journal of Engineering and Applied Sciences, 12(14), 3672-3677.

14. SUTRISNO, H. (2010). The impact of human activities to dynamic of insect communities: A case study in Gunung Salak, West Java. HAYATI Journal of Biosciences, 17(4), 161-166.

15. Hicks. James, O. (1993). Management Information System: A Users Perspectives. Publisher: West Group. Subsequent edition.

16. Whitten, P. L., \& Patisaul, H. B. (2001). Crossspecies and interassay comparisons of phytoestrogen action. Environmental health perspectives, 109(suppl 1), 5-20.

17. Taurisa, C. M., Djastuti, I., \& Ratnawati, I. (2012). Analisis pengaruh budaya organisasi dan kepuasan kerja terhadap komitmen organisasional dalam meningkatkan kinerja karyawan (Studi pada PT. Sido Muncul Kaligawe Semarang) (Doctoral dissertation, Diponegoro University).

18. Ajzen, Icek dan Fishbein. (1980). Theory of Reasoned Action, Edisi Kesatu.

19. Jan, J. E., Hamilton, D., Seward, N., Fast, D. K., Freeman, R. D., \& Laudon, M. (2000). Clinical trials of controlled- release melatonin in children with sleep-wake cycle disorders. Journal of pineal research, 29(1), 34-39.

20. Bodnar, G. H. Hopwood (2000) Sistem Informasi Akuntansi. Jakarta: Salemba Empat.

21. DeLone, W. H., \& McLean, E. R. (2003). The DeLone and McLean model of information systems success: a ten-year update. Journal of management information systems, 19(4), 9-30.

22. Petter, S., DeLone, W., \& McLean, E. (2008). Measuring information systems success: models, dimensions, measures, and interrelationships. European journal of information systems, 17(3), 236-263.

23. Baridwan, Z., \& Hariani, A. R. (2010). Insentif Untuk Memanipulasi Laba Sebagai Syarat Keefektifan Audit Yang Berkualitas Dalam Mengurangi Manipulasi Akuntansi (Indonesian). Available at SSRN 1577796. 
Trigus Sinduwarno \& Fardinal., Saudi J Bus Manag Stud, Feb, 2021; 6(2): 39-50

24. Kasmir, S., \& Carbonella, A. (Eds.). (2014). Blood and fire: Toward a global anthropology of labor (Vol. 13). Berghahn books.

25. Ronaldi, H. (2012). Analisis Faktor-Faktor yang Mempengaruhi Kinerja Sistem Informasi Akuntansi. Berkala Ilmiah Mahasiswa Akuntansi, 1(3), 70-76.

26. Respati, R. P., \& Sukirman, N. H. (2013). FaktorFaktor Yang Mempengaruhi Kinerja Sistem Informasi Akuntansi Pada Bank Umum Kota Surakarta. UPE UNS, 2(1).

27. Widiastuti, I. (2015). Sistem Informasi Akuntansi Berbasis Komputer. Jurnal Bhirawa.
28. Pradana, A., \& Salehudin, I. (2013). Role of work overload toward turnover intention among newly hired public accountants.

29. Fitrios, R. (2016). Factors that influence accounting information system implementation and accounting information quality. International Journal of Scientific \& Technology Research, 5(4), 192-198.

30. Komara, A., \& Ariningrum, H. (2013). Analisis faktor-faktor yang mempengaruhi kinerja sistem informasi akuntansi. Jurnal Riset Akuntansi dan Manajemen Malahayati, 2(1).

31. Fitrios, R. (2016). Factors that influence accounting information system implementation and accounting information quality. International Journal of Scientific \& Technology Research, 5(4), 192-198. 